\title{
Cooperative vs Competitive: Filosofi Keseimbangan "Yin-Yang" dalam Hubungan Interdependency
}

\author{
Nidya Dudija ${ }^{1}$ \\ Fakultas Ekonomi dan Bisnis Universitas Telkom, Bandung
}

\section{Pengantar}

Teori ini dikembangkan oleh Morton Deutsch (1949a, 1949b, 1973, 1985) dan juga diuraikan oleh David W. Johnson (Johnson \& Johnson, 1989). CooperativeCompetitive merupakan salah satu teori dalam psikologi sosial yang dikemukakan oleh Morton Deutch. Ilmuan evolusi sosial mengatakan bahwa altruisme manusia dan kerjasama adalah hasil dari sejarah spesies yang unik "konflik antar kelompok dan perang" (Alexander, 1987; Buss, 1999; Campbell, 1975; Tooby \& Cosmides, 1988), dapat diartikan bahwa konflik antar kelompok telah membentuk psikologi dan perilaku manusia khususnya (Vugt, Gremer, \& Janssen 2007). Penelitian psikologi sosial konsisten dengan ide ini. Dalam hal ini manusia spontan membuat perbandingan "kita vs mereka" kategorisasi dan cepat mengembangkan aspek emosional dalam kelompok bahkan ketika keanggotaan didasarkan pada kriteria yang sederhana, seperti flip koin (Brewer, 1979; Ostrom \& Sedikides, 1992; Tajfel \& Turner, 1979). Manusia juga mudah melakukan tindakan diskriminasi terhadap anggota dari luar kelompok (Fiske, 2002) dan terlibat dalam tindakan altruistik untuk membela kelompok mereka (De Cremer \& Van Vugt, 1999; Sherif , 1966).

Yin-Yang memiliki makna dimana, lingkaran luar dalam simbol Yin-Yang

\footnotetext{
${ }^{1}$ Korespondensi mengenai isi artikel ini dapat dilakukan melalui: nidyadudija@gmail.com
}

menunjukkan "everything", maksudnya keseluruhan yang ada di dunia. Kemudian Yin (Black) dan Yang (White) keduanya merupakan simbol segala sesuatu yang tak terpisahkan. Memang tidak akan pernah terjadi hitam dan putih secara bersamaan. Namun ada saatnya terjadi hitam dan ada saatnya terjadi putih. Sebuah prinsip keseimbangan yang saling mengisi dan melengkapi (Osgood, 1973). Kompetisi dan kooperatif merupakan dua pola hubungan yang terjadi dalam kehidupan manusia. Kompetisis di anggap sebagai komponen dalam challennge yang mendorong seseorang berperilaku. Sementara kerjasama merupakan salah satu bentuk insentif yang dapat menjadi penguat perilaku individu (Riyono, 2012). Bila dihubungkan dengan aliran Tao yang diyakini kaum Tionghoa. Kompetisi dan kerjasama merupakan sebuah pola keseimbangan, mengingat kompetisi dan kerjasama dibentuk olehtiga komponen psikologi yaitu: Inducibility, Substitutability, Cathexis. Dimana ke tiga hal tersebut yang menentukan perilaku individu apakah akan melakukan kompetisi atau kooperatif (Deutsch, dalam Van Lange, Kruglanski, \& Higgins 2012)

Penemuan Teori Competitive-Cooperative: Sejarah Morton Deutsch

Morton Deutsch lahir pada tahun 1920 di New York City dalam sebuah keluarga yahudi dengan tiga anak lainnya. Memiliki pengalaman yang buruk dalam kehidupan bertetangga dan sekolah karena 
tidak lepas dari ejekan, dan prasangka yang dirasakannya pada saat itu. Pada usianya yang ke-15 Tahun 1935 Deutsch terdaftar di universitas di City College of New York. Deutsch mengambil jurusan psikologi karena terpengaruh oleh tulisan Sigmund Freud yang telah dibaca sebelum memasuki jenjang kuliah. Deutsch sangat yakin untuk mendalami psikoanalisa karena bidang ini sangat dekat dan sangat relevan dengan permasalahan pribadi yang selama ini diperjuangkan, dahulu psikoanalisa juga dianggap sebagai pengetahuan yang sangat radikal (pada awal dan pertengahan tahun 1930). Selama masa remaja, Deutsch dikenal sebagai orang yang radikal dan memberontak pada kebijakan yang dianggapnya tidak sesuai. Misalnya membantu mengarahkan siswa SMA di Townsend Harris untuk melakukan pemberontakan karena meyajikan menu makan siang yang dianggap tidak layak untuk siswa sekolah. Selain itu Deutcsh juga pernah melakukan pemberontakan kepada pemilik penginapan musim panas di Camp Copake karena mengeksploitasi siswa menjadi pelayan dan Deutcsh salah satu diantaranya.

Saat berada di tingkat kedua jurusan Psikologi CCNY, Deutcsh banyak membaca tulisan Lewin mengenai psikologi sosial, psikologi kepribadian dan motivasi. Di kelas, Deutcsh juga mebaca karya-karya Lewin lainnya seperti "Dinamic Theory of Personality (1935), Principles of Topological Psychology (1936) dan The Conceptual Representation and Measurement of Psychological Psychology (1938)". Menurutnya bukubuku tersebut memberikan gambaran ilmu psikologi yang jauh berbeda dari pemahaman tradisional, memiliki penampilan karakteristik yang baru oleh lewin daripada model Aristotelian yang klasik. Bahkan dalam tulisannya Deutsch (1954) banyak terpengaruh oleh Lewin pada beberapa bagian teori psikologi dan meta teorinya. Namun meskipun Deutcsh sangat mengagumi tulisan Lewin, namun ia tetap fokus pada pilihan karirnya menjadi seorang psikolog psikoanalisa seperti tujuan awal sebelumnya. Pengalaman non-akademis yang telah dimiliki menjadi bekal pemahamannya sehingga mampu mengintegrasikan berbagai pemahaman Psikoanalisa, Marxism, dan berbagai metode ilmiah dari Lewin. Deutsch menerima gelar BS dari City College of New York pada tahun 1939 (Deutsch, 2008; Coleman, 2011)

Pada tahun 1940, setelah memperoleh gelar Master dari Clinical Psychology dari Universitas Pennsylavania, Deutcsh mulai magang pada tiga instansi di New York. Salah satunya magang di Febleminded (Letchworld Village untuk gangguan lemah mental), Deliquent Boys (Warwick) dan yang ketiga Psychotic children (Rockland State Hospital untuk anak-anak dan orang dewasa yang menagalami gangguan mental). Tanggal 7 Desember 1941 terjadi serangan di Pearl Harbour, yang membuatnya bergabung sebagai psikolog pada Angkatan Udara Amerika (US Navy) saat Deutcsh sedang menjalankan kegiatan magang psikologinya. Selama bergabung dengan Angkatan Udara, Deutsch juga berperan sebagai navigator penerbangan sehingga membuatnya terlibat dengan 30 misi serangan pemboman Jerman. Selama perang berlangsung, Deutsch banyak menyaksikan pesawat udara yang jatuh, baik milik US maupun milik Jerman. Deutsch juga turut menyaksikan ledakan besar dari bom dan kerusakan besar yang ditimbulkan selama perang berlangsung. Meskipun Deutsch memahami tujuan perang menghadapi Nazi, namun dirinya tidak menyangka kerusakan yang ditimbulkan selama perang berlangsung. Selama pertempuran 
Deutsch dikenal dengan Distinguished Flying Cross (dan cluster) dan Medal Air (dengan tiga cluster). Setelah masa tugasnya sebagai navigator penerbangan selesai Deutsch menjabat sebagai psikolog klinis di rumah sakit Angkatan Udara sampai masa tugasnya selesai.

Setelah masa perang berakhir, Deutsch memutuskan untuk mengambil program doctoral dan mendaftar di tiga universitas antara lain di University of Chicago (dimana Carl Rogers dan L.L Thurstone menjadi tokoh psikologi yang cukup dikenal), Yale University (dimana Donald Marquis sebagai ketua dan Clark Hull sebagai kepala jurusan), dan di MIT (dimana Kurt Lewin telah menghasilkan program sarjana baru dan Research Center for Group Dynamics [RCGD]). Kembali sebagai mantan prajurit perang, Deutsch tidak memiliki masalah saat interview maupun penerimaan di ketiga sekolah tersebut. Namun kekagumannya pada Kurt Lewin atas semua pencapaian dan hasil penelitian terbarunya memutuskan Deutsch untuk melanjutkan Program doktor di MIT.

Awal karir Deutsch sebagai seorang social psychologist saat pertemuan pertamanya dengan Lewin, yang menyebabkan dirinya berkomitmen untuk menuntut ilmu di Research Center for Group Dinamics (RCGD). Karir Deutsch di bidang psikologi sosial sangat banyak dipengaruhi oleh Kurt Lewin, termasuk disertasi dan orientasi keilmuan sebagai social psychologist. Lewin adalah sosok theorist yang tekun dan peneliti yang menggunakan metode menarik dengan filosofi dan metodologi ilmiah. Lewin adalah tenderhearted psychologist yang terlibat pada pengembangan pengetahuan psychological yang sangat diperlukan bagi seluruh manusia (Deutsch, 1992). Lewin adalah Panutan para ilmuwan. Seperti Lewin,
Deutsch bersikeras menjadikan teori dan penelitiannya memiliki hubungan yang sinkron dengan permasalahan sosial, Deutsch juga menginginkan hasil kerja yang detail yang akurat dan dapat diperdebatkan.

Deutsch mengangkat permasalahan dari perang dan perdamaian sebagai topik disertasinya (saat bom atom dijatuhkan di Hiroshima dan Nagasaki sebelum Deutsch melanjutkan studi) serta gambaran negara-negara yang saling berinteraksi dan bersatu untuk menciptakan perdamaian. Namun kematian Lewin yang mendadak, membuat Deuscth mengubah topik disertasi yang awalnya memperhatikan dinamika sosial mengenai dampak perang nuklir, kini lebih berorientasi untuk menyelidiki teori dari proses persaingan. Masalah yang membuat Deutsch tertarik adalah lebih pada bentuk yang umum, berupa pemahaman hubungan kooperatif dan kompetisi serta konsekuensinya yang berbeda dari hubungan saling ketergantungan dalam hubungan antar individu atau antar kelompok. Pada tahun 1948 Deutsch menulis disertasinya membandingkan efek psikologis dan produktivitas kelompok Cooperative dan kelompok Compepetitive. Deutsch bekerja pada bagian Pusat Penelitian Lewin untuk Dinamika Kelompok, dimana penelitian awal sebagian besar diwarnai oleh kekhawatiran global yang terus meningkat oleh dampak perang nuklir. Deutsch juga bertugas mengajar di kelas pengantar psikologi, kepada mahasiswanya Deutsch melakukan percobaan membandingkan proses penilaian Cooperative dan Competitive.

Disertasi Deutsch tidak hanya dipengaruhi oleh teori Lewin yang tertarik pada social interdependence, namun teori Marxist yang mengungkapkan perbedaan sistem keadilan: kerja sama - egalitarian dan persaingan - meritocratic. Tulisan dari 
George Herbert Mead (1934) memengaruhi pemikiran Deutsch tentang kerjasama dan ini penting untuk perkembangan umat manusia. Ditambah lagi, diskusi tentang hubungan antara social objektif interdependence dan perceived social interdependence telah banyak dipengaruhi oleh Koffka (1935), menjawab pertanyaan "Mengapa harus melakukan hal yang sama seperti mereka?". Sejauh ini, karya sastra yang Deutsch baca mengenai kerja sama - persaingan (Barnard, 1938; Lewin, 1948; Maller, 1929; May \& Doob, 1937; Mead, 1934; Mead, 1937) sangat jelas telah memengaruhi pekerjaannya.

Hal ini menyebabkan Deutsch memiliki kontribusi teoritis utama yang dibuat selama awal karirnya yaitu "Teori Kerjasama dan Persaingan", yang mempelajari saling ketergantungan antara tujuan (Cooperative VS Competitive) dan jenis tindakan yang diambil (Bunggling Action VS Effective Action). Penelitian ini menggunakan tiga konsep untuk mengembangkan implikasinya terhadap proses-proses sosial dan hubungan personal yang terjadi pada kelompok anatar lain: substitusi (bagaimana tindakan seseorang mampu memenuhi niat orang lain), cathexis (disposisi individu untuk mengevaluasi diri atau lingkungannya), dan inducibility (kesiapan individu untuk menerima pengaruh orang lain) (Deutsch, dalam Van Lange, Kruglanski, \& Higgins 2012).

\section{Kerjasama Versus Kompetisi}

Teori ini di dasarkan pada dua ide: Pertama, berhubungan dengan tipe keadaan saling tergantung diantara tujuan masyarakat yang terlibat dalam menciptakan suasana. Kedua, jenis tindakan yang dilakukan oleh orang-orang yang terlibat. Kemudian tipe dasar saling ketergantungan di identifikasi menjadi dua hal: Positif (di mana tujuan dihubungkan sedemikian rupa sehingga jumlah atau probabilitas pencapaian tujuan seseorang berkorelasi negative dengan jumlah atau probabilitas pencapaian tujuan lain). Dalam mengembangkan teori, Deutsch (1973) mengasumsikan bahwa anggota tim bekerja untuk memajukan kepentingan diri mereka dengan berjuang untuk mencapai tujuan mereka. Akan Tetapi, mengejar kepentingan pribadi tidak menghalangi perkembangan hubungan yang produktif dan kerja sama tim. Deutsch berpendapat bahwa tujuan yang dianggap terstruktur menentukan bagaimana orang berinteraksi, dan pola interaksi ini akan menentukan hasil (Deutsch, 1973; Johnson \& Johnson, 1989; Johnson, Maruyama, Johnson, Nelson, \& Skon, 1981; Stanne, Johnson \& Johnson, 1999).

Tujuan dapat dianggap kooperatif, kompetitif, atau secara independen terkait. Dalam kerjasama, orang menyimpulkan bahwa prestasi tujuan mereka berkorelasi positif; mereka percaya bahwa mereka dapat mencapai tujuan mereka jika orang lain juga mencapai tujuan mereka. Dalam kompetisi, orang percaya bahwa prestasi tujuan mereka berkorelasi negatif; masingmasing merasakan bahwa suatu pencapaian melarang atau setidaknya memperkecil kemungkinan bahwa orang lain akan mencapai tujuan mereka. Dengan tujuan independen, prestasi dianggap tidak terkait. Anggota tim memahami bahwa tujuan mereka sendiri terkait kooperatif atau kompetitif memengaruhi harapan mereka, interaksi, dan hasil. Dengan tujuan kooperatif, anggota tim percaya bahwa salah satu bergerak ke arah pencapaian tujuan, dan yang lain bergerak ke arah pencapaian tujuan mereka. Mereka memahami bahwa orang lain membantu mereka dalam mencapai tujuan; mereka bisa sukses bersama-sama. Akibatnya, orang satu sama lain ingin bekerja efektif, 
untuk membantu setiap orang menjadi sukses. Mereka mengharapkan satu sama lain untuk menggunakan kemampuan mereka untuk bekerja dan saling menguntungkan (Lewicky, McAllister, \& Bies, 1998). Tiga jenis hubungan tujuan belum tentu independen satu sama lain; jenis dominan tujuan hubungan akan memainkan peran utama dalam memengaruhi proses interaksi.

Penelitian telah menunjukkan bahwa dengan tujuan kooperatif, dibandingkan dengan yang kompetitif, anggota kelompok terlibat dalam pengolahan informasi yang lebih disengaja dan menyeluruh. Para anggota tim yang lebih merasakan hubungan kerja sama, semakin mereka berbagi informasi dan mendiskusikan perbedaan pendapat mereka secara langsung dan, akibatnya, semakin mereka belajar menjadi lebih efektif (De Dreu, 2007; Johnson \& Johnson, 1989, 2005; Tjosvold, 1988). Meskipun persaingan dan tidak ketergantungan bermanfaat pada kondisi tertentu, hasil penelitian telah menunjukkan bahwa anggota tim yang memiliki tujuan kooperatif, daripada tujuan yang kompetitif dan mandiri, memiliki dinamika interaksi yang lebih efektif (Chen \& Tjosvold, 2002; Crown \& Rosse, 1995; Tjosvold, Tang, \& West, 2004; Tjosvold \& $\mathrm{Yu}, 2007)$. Dimana tujuan kooperatif membentuk kontroversi konstruktif, sehingga menghasilkan percaya diri, kreatif, dan kerja sama tim yang produktif (Lu, JiaFang, Tjosvold, \& Shi, 2010)

\section{Proses Psikologis Kerjasama dan Kompetisi}

Ketiga konsep yang disebutkan sebelumnya, substitutability, cathexis, and inducibility sangatlah penting untuk proses psikologi sosial yang terlibat dalam menciptakan dampak utama dari kerjasama and kompetisi. Pendekatan substitutability (bagaimana tindakan orang dapat membe- rikan kepuasan pada tujuan orang lain) sangat penting bagi seluruh institusi sosial (keluarga, industri, sekolah), untuk pembagian tenaga kerja, dan spesialisasi peran. Substitutability membuat individu menerima perbuatan orang lain dalam memenuhi kebutuhan. Negative substitutability memberikan penolakan aktif dan dorongan untuk meniadakan dampak dari aktifitas orang lain. (Deutsch, dalam Van Lange, Kruglanski, \& Higgins 2012).

Cathexis berhubungan tentang kecenderungan respons secara evaluatif, positif atau negatif pada aspek suatu lingkungan atau diri sendiri. Melalui seleksi alam dan evolusi (perkembangan) bahwa semua makhluk hidup memiliki kapasitas respons yang positif untuk mendorong hal menguntungkan bagi mereka dan negative bagi yang berbahaya untuk mereka. Manusia tertarik pada, pendekatan, penerimaan, proses, peningkatan dan berlaku positif terhadap objek/peristiwa atau individu lain yang menguntungkan. Sebaliknya, Individu akan menghindari/berperilaku negatif pada objek yang berbahaya, kenyataan dan penghindaran, penolakan, serangan, ketidaksukaan, meniadakan. Kecenderungan manusia yang sudah ada sejak lahir yaitu bertindak positif terhadap yang menguntungkan dan bertindak negatif pada yang membahayakan adalah fondasi dari potensi manusia untuk kerjasama dan kompetisi. Dasar orientasi psychological dari tingkah positif penerapan kerja sama, "Kita ada untuk saling membantu", "Kita berguna untuk satu sama lain"; berbeda hal dengan persaingan "Kita ada untuk saling melawan" , "Kamu adalah kerugian bagi saya".

Inducibility memiliki maksud tentang kesiapan untuk menerima pengaruh lain agar dilakukan sebagai apa yang dia butuhkan; sedangkan negative inducibility 
penolakan dari kesiapan. Komplemen dari substitutability dan inducibility. Menjadikan individu saling membantu satu sama lain, kepada individu yang membantu, namun tidak dengan individu yang berbahaya. Pada kenyataannya, jika anda menolak permintaan ajakan yang berbahaya, masih ada kemungkinan untuk menolak atau menerima/bergabung. Hubungan anatara ketiga komponen tersebut dapat digambarkan seperti pada Gambar 1.

Berdasarkan Gambar 1, dapat dijelaskan ketiga hubungan komponen psikologis dalam kerjasama dan kompetisi bahwa Inducibility, Sustitability dan Cathexis merupakan unsur-unsur psikologis yang membentuk perilaku Cooperative dan Competitive. Dimana perilaku tersebut akan terbentuk oleh kekuatan antara unsur Inducibility dan Sustitability yang berusaha untuk saling mendorong satu sama lain dan akan diseimbangkan oleh respons yang positif atau negatif dari cathexis sehingga dapat menghasilkan perilaku yang competitive/cooperative dalam hubungan antar individu/kelompok yang didasarkan oleh keadaan saling tergan- tung diantara tujuan individu yang terlibat dalam menciptakan suatu kondisi dan jenis tindakan yang dilakukan oleh individu yang terlibat.

Keadaan ini bila dikaitkan dalam Filosofi "Yin-Yang" sangat erat kaitannya dimana "Yin-Yang" merupakan konsep dalam filosofi Tionghoa yang biasanya digunakan untuk mendeskripsikan sifat kekuatan yang saling berhubungan dan berlawanan di dunia ini dan bagaimana mereka saling membangun satu sama lain. Yin dan Yang saling berlawanan dalam interaksi dengan dunia yang lebih luas dan sebagai bagian dari sistem yang dinamis. Yin dan Yang selalu bertolak belakang, namun penerapannya dalam hidup harus seimbang. Apabila tidak maka akan menimbulkan ketidakserasian dalam kehidupan. Keseimbangan Artinya dalam ajaran Yin yang semua diajarkan harus secara seimbang, serasi dan selaras. Meskipun semuanya bertentangan haruslah tetap diseimbangankan, keberadaan hitam adalah untuk menyeimbangkan adanya putih (Osgood, 1973).

Merujuk pada filosofi Yin-Yang kom-

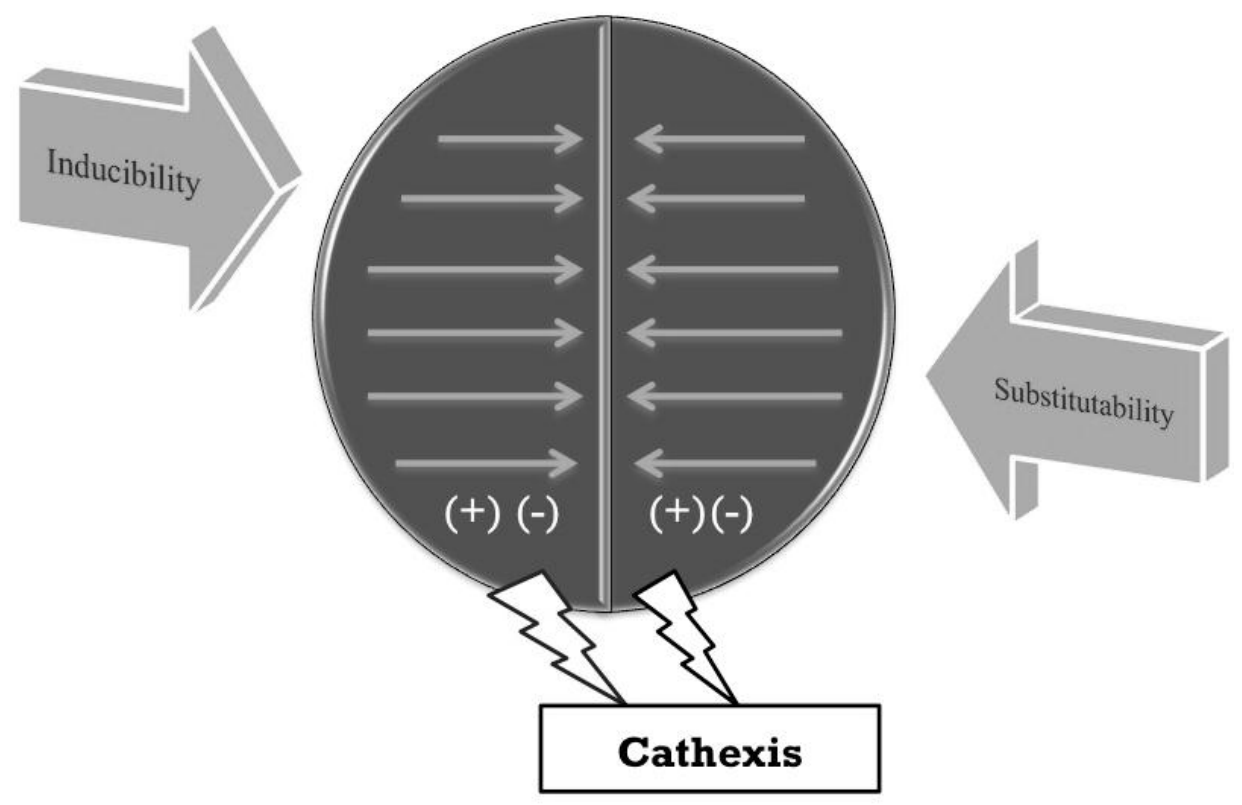

Gambar 1. Hubungan Komponen Psikologis dalam Cooperative-Competitive 
ponen psikologis Inducibility mengacu pada kesiapan untuk menerima (positive inducibility) atau menolak (negative inducibility) memenuhi keinginan/pengaruh orang lain (melakukan apa yang orang lain inginkan) yang dapat diibaratkan memiliki sifat "Yin", sementara Substitutatbility, Substitusi positif memungkinkan individu untuk menerima aktivitas orang lain dalam memenuhi kebutuhannya Substitusi negatif berkaitan dengan penolakan aktif serta berupaya untuk melawan efek dari aktivitas orang lain yang bila diibaratkan memiliki sifat "Yang", Sementara Cathexis merupakan responss positif (mendekati, menerima, menyukai, bertindak positif) terhadap stimulus (peristiwa, situasi, dan objek) yang menguntungkan yang dapat membentuk sifat positif (kooperatif) namun dapat juga menjadi responss negatif (menghindari, menolak, menyerang, tidak menyukai, bertindak negatif) terhadap stimulus yang mengancam sehingga akan menimbulkan sifat negatif (kompetisi). Dimana kedua perilaku ini dapat muncul seiring sejalan, selaras dan seimbang tergantung pada konteks (alasan individu berperilaku untuk mencapai tujuannya) mengikuti kondisi lingkungan yang dinamis.

\section{Dampak Kerjasama dan Kompetisi}

Dalam dunia pendidikan pembelajaran cooperative dan competitive diperlukan untuk mengarahkan pada tujuan kinerja sebagai hasil yang diinginkan dari pengalaman pendidikan. Pembelajaran kompetitif adalah yang paling tepat ketika siswa harus melihat materi belajar. Hal ini dapat interpersonal (antar individu) atau antar kelompok (antara kelompok-kelompok), (Johnson et al., 1986). Ketika persaingan terjadi antara pesaing yang sesuai, dilakukan tanpa adanya sistem penilaian norma - direferensikan, dan tidak digunakan terlalu sering, dapat menjadi cara yang efektif untuk memotivasi siswa untuk saling bekerja sama (Cohen, 1994). Pembelajaran kooperatif adalah cara belajar di mana siswa dari berbagai tingkat kemampuan bekerja sama dalam kelompok kecil untuk mencapai tujuan (Akinbobola, 2006). Siswa dalam kelompok berinteraksi satu sama lain berbagi ide dan informasi, mencari informasi tambahan, membuat keputusan tentang temuan mereka kepada seluruh kelas (Kort, 1992). Pembelajaran kooperatif adalah student centered dibandingkan teacher centered menuju penekanan kuat pada tujuan belajar bukan pada tujuan kinerja. Hal ini mendorong para guru untuk menggunakan teknik penilaian alternatif lebih mengurangi penekanan pada ujian kompetitif (Slavin, 1992). Pressel (1992), berpendapat bahwa pembelajaran kooperatif membantu meningkatkan prestasi siswa dan retensi, meningkatkan harga diri dan motivasi intrinsik dan mengembangkan sikap yang lebih positif terhadap kemampuan belajar dan keterampilan sosial.

Menurut Akinbobola (2006) sistem pendidikan saat ini didasarkan pada kompetisi antar siswa untuk kelas, pengakuan sosial, beasiswa dan masuk ke sekolahsekolah terbaik. Dikatakan bahwa dalam masyarakat persaingan kerangka pendidikan saat ini bernilai lebih dari kerjasama. Kompetisi siswa kelas akan masuk ke dalam kurva kelas dengan nilai masingmasing. (Stahle, 1986) berpendapat bahwa ditekankan untuk melakukan lebih baik daripada orang lain. Kompetisi mendorong situasi menang-kalah dimana siswa unggul mendapatkan manfaat dan pengakuan sementara siswa yang biasabiasa saja atau menghasilkan nilai yang rendah tidak akan mendapatkan apa-apa (Johnson \& Johnson, 1989). Hal ini sejalan dengan competitive contest menurut 
Deutsch (Van Lange, 2010) bahwa Competitive contest merupakan suatu proses yang bertujuan untuk membangun nilai yang berbeda sehingga selalu ada posisi menang dan kalah.

\section{Teori Resolusi Konflik: Constructive VS} Destructive

Kompetisi dapat berubah dari yang Destructive (menghancurkan) menjadi Constructive (membangun); kompetisi yang tidak memiliki peraturan yang jelas dan tidak adil akan membawa pada resolusi konflik yang destructive. Sementara kompetisi yang adil, dan memiliki peraturan yang jelas akan menghasilkan resolusi konflik yang positif dan konstrutif. Dalam kompetisi yang tertib, yang kalah akan mendapatkan hal yang sama seperti pemenang. Contoh, dalam kompetisi pertandingan tenis memiliki bentuk yang konstruktif, pemenang menunjukkan bagaimana kalah dapat memberikan kesempatan untuk belajar dan mempraktekan keterampilan. Dalam kompetisi constructive, pemenang memastikan bahwa kalah lebih baik daripada tidak mengikuti kompetisi sama sekali (Deutsch, dalam Van Lange, Kruglanski, \& Higgins 2012).

Sebagai contoh perbedaan yang tampak diantara konstruktif kontroversi yang tertib dan persaingan dalam debat diantara pemimpin, mereka membicarakan perbedaan pendapat mereka secara objektif dan mencari solusi adalah jalan terbaik selama diskusi. Tidak ada yang menang dan yang kalah; semuanya adalah pemenang jika selama pertandingan masing-masing pihak mampu mengontrol diri. Kontroversi konstruktif adalah proses untuk mengatasi perbedaan, individu melakukan interaksi kooperatif karena menggunakan perbedaan pemahaman, perspektif, pengetahuan dan di seluruh dunia sebagai sumber daya yang berharga. Berbeda dengan compettitive contest atau debat, selalu ada yang menang dan yang kalah. Harus ada yang terbaik secara ide, kemampuan, pengetahuan, dan lainnya. Persaingan mengevaluasi orang berdasarkan peringkat kemampuan mereka untuk suatu tugas tertentu, dibandingkan mengintegrasikan berbagai kontribusi.

Penelitian lain telah menunjukkan bahwa tujuan kooperatif mengembangkan kontroversi konstruktif, yang didefinisikan sebagai diskusi terbuka menentang pandangan untuk saling menguntungkan (Tjosvold, 1988, 1998). Dengan kooperatif, bukan saling ketergantungan tujuan kompetitif dan mandiri, anggota kelompok cenderung percaya bahwa mereka dapat mengandalkan satu sama lain, menangani pandangan mereka yang beragam lebih konstruktif dan manfaat dari pertukaran ini dan diskusi informasi, baik sebagai individu dan sebagai sebuah tim. Orang dengan tujuan kooperatif berbeda dengan kompetitif dan mandiri tujuan telah ditemukan untuk mengekspresikan pandangan mereka menentang secara langsung dan bekerja untuk mengintegrasikan sehingga mereka dapat mengembangkan solusi berkualitas tinggi (Tjosvold, 1998). Tujuan kooperatif adalah dimana anggota tim dapat mengandalkan satu sama lain dan akan mempertimbangkan masingmasing ide membahas perspektif masingmasing secara terbuka.

\section{Orientasi Psikologis dalam Hubungan Sosial}

Deutsch dan Myron (dalam, Hope dkk., 1976 ) mengidentifikasi dimensi dasar hubungan sosial, yaitu; Kerjasamakompetisi, power distribution; berorientasi tugas Versus sosial-emosional, Formal versus informal, Tingkat kepentingan. Beberapa di antaranya telah dijelaskan oleh peneliti lain . 
Untuk bertindak tepat dalam suatu jenis hubungan sosial seseorang harus memiliki orientasi psikologis yang sesuai dengan hubungan sosial tersebut (orientasi psikologis seseorang harus "sesuai" dengan hubungan sosial). Deutsch mencontohkan Misalnya, orientasi psikologis individu ketika melakukan negosiasi harga mobil dengan penjual mobil bekas akan berbeda orientasi psikologisnya ketika bermain dengan cucu. Berbagai jenis hubungan sosial akan mendorong berbagai jenis orientasi psikologis, dan, menurut "Crude Law" jenis orientasi psikologis akan mendorong berbagai jenis hubungan sosial (Deutsch, dalam Van Lange, Kruglanski, \& Higgins 2012).

\section{Sifat orientasi psikologis}

Orientasi psikologis terdiri dari empat elemen yang saling tergantung: orientasi kognitif, orientasi motivasi, orientasi moral dan orientasi tindakan (Deutsch 1982, 1985)

\section{Orientasi Kognitif}

Dalam pandangan ini, orientasi kognitif seseorang untuk situasi hanyalah salah satu aspek dari orientasi psikologis pada hubungan sosial. Jenis hubungan sosial dalam konteks yang berbeda dan dengan berbagai macam individu akan menghasilkn orientasi kognitif yang abstrak hasil dari berbagai jenis hubungan sosial. Menurut Deutsch ahli teori psikologi telah mengembangkan skema kognitif berbagai jenis hubungan sosial

\section{Orientasi Motivasi}

Orientasi motivasi secara personal berupa pandangan subjektif yang timbul dari motif seseorang secara situasional yang relevan atau membutuhkan disposisi. Orientasi motivasi melahirkan cathexis dari area kognitif, membuat mereka positif atau negatif. Memberikan peta kognitif yang dinamis Hal ini mengarahkan seseorang untuk pertanyaan seperti "apa yang akan dinilai dalam hubungan ini? "dan" apa yang saya inginkan di sini dan bagaimana cara saya mendapatkannya?"

\section{Orientasi Moral}

Orientasi moral yang menuju hubungan sosial seseorang langsung diberikan menjadi kewajiban bersama, hak dari orang yang terlibat dalam hubungan. Orientasi moral yang menunjukkan bahwa seseorang mengalami hubungan seseorang tidak hanya dari perspektif pribadi, tetapi juga dari perspektif sosial yang meliputi perspektif lain dalam hubungan. Orientasi moral yang membuat pengalaman ketidakadilan lebih dari pengalaman frustasi pribadi (Deutsch, dkk., 1978). Tidak hanya berpengaruh secara pribadi, tetapi pada peserta lain yang terlibat dalam hubungan, karena dasar-dasar nilai sedang dirusak. Setiap individu dalam suatu hubungan memiliki kewajiban bersama untuk menghormati dan melindungi norma-norma sosial untuk menentukan apa yang harus dianggap adil atau tidak adil dalam interaksi dan hasil dari para peserta.

\section{Orientasi Tindakan}

Orientasi aksi mengacu pada jenis perilaku yang dipandang sesuai dengan jenis tertentu dari hubungan sosial. Budaya yang berbeda sering memiliki pandangan yang berbeda mengenai perilaku yang sesuai dalam hubungan sosial tertentu. Jadi aku merasa sangat senang dengan hasil negosiasi saya dengan penjual mobil bekas (aku punya harga yang sangat baik), itu akan menjadi perilaku yang sesuai untuk mengekspresikan kesenangan saya dengan menciumnya . 
Komponen moral yang ada di semua hubungan sosial sebagian besar telah diabaikan dalam teori psikologi sosial. Saya menyarankan bahwa orientasi moral, apa yang dianggap adil atau tidak adil, akan bervariasi dalam berbagai jenis hubungan sosial, biarkan aku menggambarkan komponen moral beberapa jenis hubungan sosial

\section{Kesetaraan - ketidaksetaraan}

Ada beberapa orientasi moral yang terhubung dengan kesetaraan dan ketidaksetaraan: distribusi kekuasaan di dalamnya akan menentukan sifat yang menimbulkan orientasi moral. Dalam kerjasama, hubungan yang setara (equal) yang diharapkan hubungan egaliter. Dalam kerjasama, hubungan yang tidak setara (unequal) orientasi moral yang mewajibkan orang yang lebih kuat untuk menggunakan kekuasaannya sedemikian rupa untuk memperoleh keuntungan. Hubungan seperti itu, yang kurang kuat memiliki kewajiban untuk menunjukkan penghargaan, untuk tunduk dan menghormati orang yang lebih kuat. Kewajiban ini mungkin agak spesifik dan terbatas jika hubungan berorientasi tugas atau mereka mungkin menyebar dan umum jika hubungan adalah salah satu yang emosional sosial

Dalam kesetaraan (equal), hubungan kompetitif, orientasi moral seseorang adalah menuju nilai kesetaraan awal di antara pesaing dan selanjutnya berusaha untuk mencapai keunggulan atas yang lain. Orientasi ini memiliki kesempatan yang sama tapi tidak hasil yang sama: pesaing memulai kompetisi dengan kesempatan yang sama untuk menang, tetapi hasilnya ada yang menang dan kalah. Kondisi tidak sama (unequal), hubungan kompetitif orientasi moral yang kuat dan dukungan yang lemah menghasilkan hubungan yang eksploitatif. Yang kuat cenderung mengadopsi pandangan bahwa orang kaya yang berkuasa secara biologis dan karenanya memiliki aspek moral superior. Mereka telah mencapai posisi unggul sebagai hasil dari seleksi alam; itu akan melawan alam untuk mengganggu ketidaksetaraan dan penderitaan kaum miskin dan lemah; dan itu adalah takdir nyata dari orang-orang yang unggul untuk memimpin orangorang rendah. Yang tidak setara (unequal), hubungan kompetitif, yang lemah cenderung untuk mengidentifikasi dengan agresor (Freud 1937) dan mengadopsi orientasi moral yang lebih kuat dan merasa yang mereka hasilkan layak. Atau yang lemah cenderung merasa menjadi korban golongan yang kuat (Deutsch, dalam Van Lange, Kruglanski, \& Higgins 2012). Hubungan kesetaraan dan ketidaksetaraan dalam hubungan kooperatif dan kompetitif yang menghasilkan orientasi moral dapat dilihat pada Gambar 2.

\section{Diskusi}

Meskipun berasal dari Barat, teori kerjasama dan kompetisi terbukti berguna untuk menganalisis dan memperkuat kerja sama tim baik di dalam dan di antara tim dalam organisasi. Contohnya pada penelitian yang telah dilakukan di Cina (Chen, G., \& Tjosvold, D., 2002). Hasil penelitian tersebut mendukung pemahaman bahwa tujuan koperatif dan kontroversi konstruktif menjadi dasar untuk memahami dan mengembangkan kerja sama tim yang produktif dalam organisasi. Anggota tim dengan tujuan kooperatif yang kuat, akan memiliki tujuan yang positif, mampu mendiskusikan pendapat yang beragam dengan pikiran terbuka dan menggunakan diskusi ini untuk saling menguntungkan. Keterbukaan ini, pada gilirannya, ditemukan untuk memprediksi potensi kelompok, kreatif mengembangkan cara-cara 


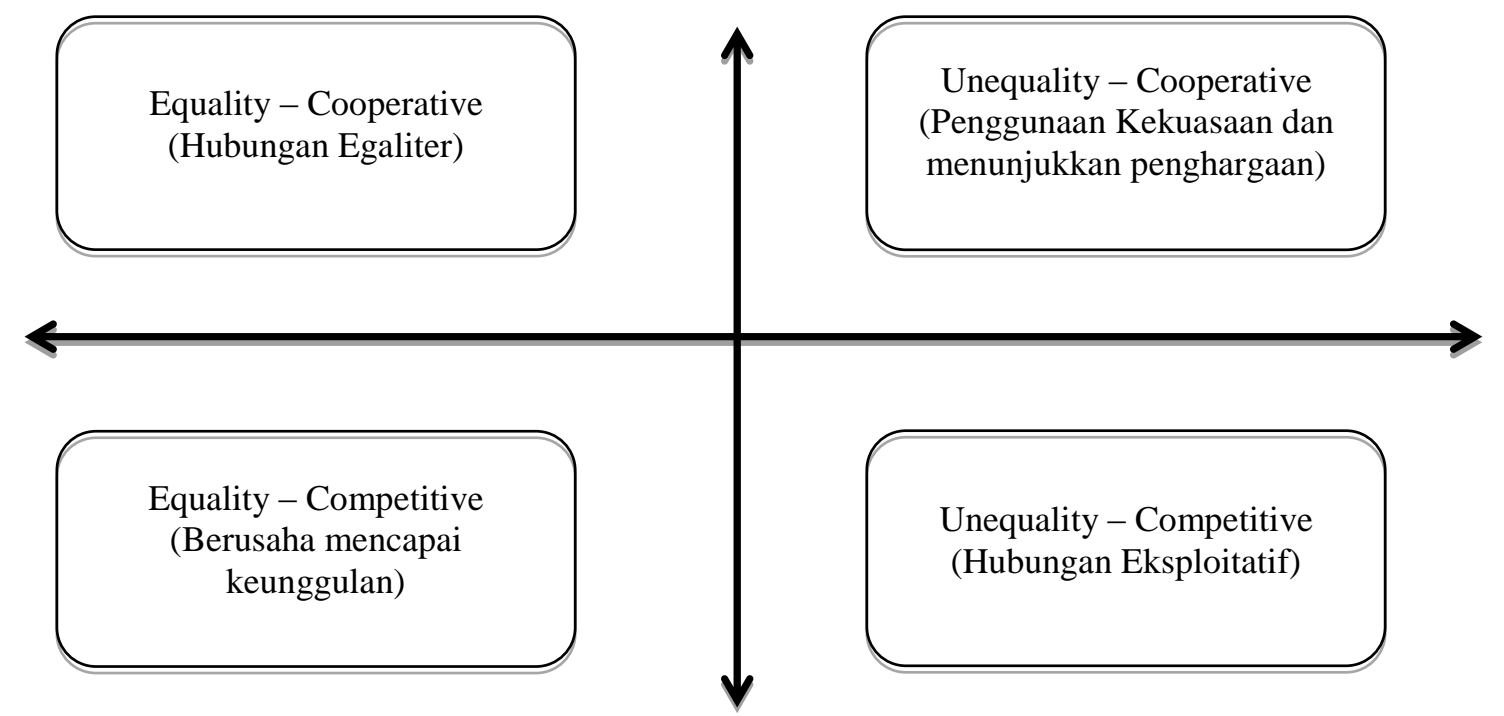

Gambar 2. Hubungan Kesetaraan dan Ketidaksetaraan dalam Hubungan Kooperatif dan Kompetititf (Sumber: Deutsch, dalam Van Lange, Kruglanski, \& Higgins 2012).

kerja yang inovatif dan kerja yang produktif (Fang Lu-Jia, Shi K., \& Tjosvold, D. 2010). Hasil ini konsisten dengan hasil meta-analisis bahwa kerjasama antar kelompok lebih mendukung produktivitas dalam kelompok dibandingkan persaingan antar kelompok (Johnson et al., 1981). Meskipun terjadi persaingan antar kelompok dan sering dianggap untuk merangsang kohesifitas dalam kelompok, kerjasama antar kelompok umumnya menyediakan dasar yang lebih produktif bagi tim, terutama dalam organisasi tempat tim yang saling tergantung.

Penelitian sebelumnya mengatakan bahwa tim dalam sebuah organisasi mengalami kesulitan dalam mengembangkan kerjasama yang kompetitif di antara mereka (Jackson et al., 2003). Tim dalam organisasi umumnya memiliki lebih banyak kesempatan untuk mengembangkan pribadi, hubungan kerjasama; sedangkan pelatihan kerja tim dapat memperkuat hubungan antar kelompok. Penelitian diperlukan untuk menguji spekulasi ini. Peneliti lintas - budaya berpendapat bahwa kolektivis orang Cina berorientasi menghindari konflik, dan telah mengem- bangkan data yang menunjukkan bahwa mereka mungkin lebih cenderung untuk mendukung menghindari konflik dari orang-orang dari Barat (Ting - Toomey \& Oetzel, 2001; Tse , Francis, \& Walls , 1994). Namun, temuan dari studi ini menggarisbawahi bahwa orang-orang Cina, ketika mereka percaya bahwa tujuan mereka adalah kerjasama, mereka siap untuk mendiskusikan pandangan mereka secara terbuka dan dapat menggunakan jenisjenis diskusi yang produktif .

Sejalan dengan temuan ini, (Leung, 1996; Leung, Koch, \& Lu, 2002) berpendapat bahwa nilai-nilai Cina yang harmoni dapat mengambil bentuk yang sangat berbeda dan motivasi yang melatarbelakanginya. Orang Cina menghindari konflik untuk mengejar tujuan lain; tetapi ketika mereka mencari keseimbangan yang harmonis untuk memperkuat hubungan itu sendiri, mereka bersedia dan mampu mendiskusikan perbedaan mereka secara terbuka dan konstruktif. Eksperimen dan studi lapangan baru-baru ini telah didukung lebih lanjut penalaran yang dengan tujuan kerjasama, orang Cina menyambut diskusi yang saling berten- 
tangan dan dapat menggunakannya untuk memahami dan mengembangkan solusi untuk masalah, serta memperkuat hubungan mereka (Chen, Liu, \& Tjosvold, 2005; Tjosvold \& Sun, 2000). Penelitian ini menunjukkan bahwa mengembangkan organisasi kolektif secara keseluruhan untuk memperkuat tujuan kooperatif dan untuk mendukung dan mendorong diskusi terbuka tentang perbedaan dapat menjadi landasan bagi orang-orang Cina untuk membuat pandangan yang efektif bahwa potensi kelompok, kreativitas, dan produktivitas semua ditemukan dari tujuan yang kooperatif dan kontroversi konstruktif.

Ditemukan juga pada hasil penelitian Kolawole (2008) mengenai pengaruh pembelajaran kooperatif dan komperatif pada performa akademik dihasilkan bahwa: (a) Strategi pembelajaran kooperatif lebih efektif daripada strategi pembelajaran kompetitif dalam mengajar matematika di tingkat Sekolah Menengah Atas; (b) Para siswa laki-laki secara signifikan lebih baik daripada rekan-rekan perempuan mereka dalam belajar matematika dengan strategi pembelajaran kooperatif dan kompetitif. (c) Ada pengaruh jenis kelamin terhadap kinerja matematika melalui strategi pembelajaran kooperatif dan kompetitif. (d) Anak laki-laki yang diajarkan dengan strategi pembelajaran kooperatif yang dilakukan secara signifikan lebih baik dibandingkan anak perempuan diajarkan dengan strategi pembelajaran kompetitif di matematika, dan (e) Strategi pembelajaran kooperatif lebih efektif daripada strategi pembelajaran kompetitif dalam pengajaran matematika di Nigeria.

Dalam uji validitas konvergen, kolektivisme ditemukan menyatu dengan kerjasama pada survei nilai Rokeach dan skala kerjasama Johnson (Triandis, Leung,
Villareal, \& Clac, 1985). Diaz - Guerrero (1984) menemukan bahwa kolektivis menekankan nilai kerja sama, sedangkan individualis menekankan persaingan. Leung (1988) menemukan bahwa kolektivis lebih menyukai pendekatan kooperatif seperti tawar-menawar dan mediasi untuk penyelesaian konflik. Sementara, Wagner dan Moch (1986) menemukan bahwa individualisme - kolektivisme terkait dengan jenis pekerjaan. Kolektivis cenderung untuk melakukan pekerjaan yang diperlukan kerja sama tim dan individualis melakukan tugas lebih mandiri. Selain itu, mereka menemukan bahwa perbandingan imbalan kolektif terus berkurang untuk individualis daripada kolektivis karena imbalan tersebut harus di konsumsi bersama daripada dikonsumsi secara pribadi. Studi ini memberikan bukti empiris bahwa perbedaan kelompok etnis memengaruhi setidaknya beberapa aspek perilaku dalam kelompok tugas. Studi ini menemukan bahwa pada tingkat individu, Asia, Hitam, dan individu Hispanik memiliki orientasi yang buruk mengenai kolektivis - kooperatif untuk tugas daripada Anglo. Temuan ini konsisten dengan penelitian sebelumnya dan teori menunjukkan bahwa perbedaan-perbedaan ini berasal dari perbedaan budaya nasional di mana berbagai kelompok memiliki akar budaya. Kami lebih lanjut menemukan bahwa kita bisa memanfaatkan pengetahuan ini perbedaan tingkat individu untuk memprediksi perbedaan perilaku kelompok pada pengambilan keputusan tugas kelompok.

Beberapa peneliti telah meneliti efek dari persaingan antarkelompok dibandingkan dengan kondisi murni kooperatif. Stanne dkk. (1999) hasil meta-analisis menunjukkan bahwa persaingan antarkelompok dapat meningkatkan kinerja dalam lingkungan kerja (Erev, Bornstein, \& Galili, 1993), kelompok produktivitas 
(Mulvey \& Ribbens, 1999), dan kinerja akademik (Okebukola, 1985, 1986). Deci, Betley, Kahle, Abrams, dan Porac, Pampanga (1981) menemukan bahwa persaingan merusak motivasi intrinsik. Peserta yang telah bertanding melawan peserta lain tidak mungkin untuk kembali ke aktivitas sebelumnya dibandingkan individu yang tidak bersaing. Deci dkk., (1981) berpendapat bahwa fokus peserta memenangkan bukan pada aktivitas itu sendiri bertanggung jawab untuk ini penurunan motivasi intrinsik. Penelitian yang lebih baru telah menunjukkan potensi positif kompetisi pada motivasi intrinsik, menunjukkan bahwa persaingan dapat memiliki efek positif untuk jenis tertentu individu atau dalam situasi tertentu (Epstein \& Harackiewicz, 1992; Reeve \& Deci, 1996; Tauer \& Harackiewicz, 1999).

Harackiewicz dan Sansone (1991); Sansone dan Harackiewicz, (1996) membedakan dua cara kompetisi yang dapat memengaruhi motivasi intrinsik. Pertama adalah konteks kompetitif dijelaskan pada awal suatu kegiatan, yang dapat memengaruhi bagaimana individu menyelasiakan tugas. Kedua adalah melalui umpan balik kinerja, yang biasanya datang pada akhir dari suatu kegiatan. Penelitian telah menunjukkan bahwa konteks kompetitif dapat meningkatkan baik penilaian kompetensi (atau keinginan untuk melakukannya dengan baik) dan rasa tantangan atau kegembiraan, yang dapat meningkatkan motivasi intrinsik (Epstein \& Harackiewicz, 1992; Harackiewicz \& Manderlink, 1984; Reeve \& Deci 1996; Tauer \& Harackiewicz, 1999). Dengan demikian, persaingan dapat memiliki efek positif karena menimbulkan tantangan yang menarik dan/atau meningkatkan pentingnya sebuah tempat individu pada melakukan dengan baik.
Sehingga individu dapat menjadi lebih terlibat dalam kegiatan ini, sehingga meningkatkan motivasi intrinsik.

\section{Penutup}

Cooperative-Competition merupakan kegiatan yang dapat menyebabkan orientasi psikologis dalam hubungan sosial. Dimana Substitubility, Cathexis, dan Inducibility merupakan tiga proses psikologis yang terlibat dalam Cooperative-Competition. Perilaku tersebut akan terbentuk oleh kekuatan antara unsur Inducibility dan Sustitability yang berusaha untuk saling mendorong satu sama lain dan akan diseimbangkan oleh respons yang positif atau negatif dari cathexis sehingga dapat menghasilakan perilaku yang competitive/ cooperative dalam hubungan antar indivi$\mathrm{du} /$ kelompok. Sementara itu hubungan sosial dikarateristikkan tidak hanya dari sudut pandang kerjasama - persaingan tetapi berbagai aspek seperti: kesamaan ketidaksamaan; task-oriented versus socialemotional-orientasi (Gemeinschaft versus Gesellschaft); formal versus informal; dan degree of importance. Orientasi secara psikologi diikuti komponen: kognitif, motivasi, moral, dan aksi orientasi. Tetapi orientasi psikologis dapat mengakibatkan hubungan sosial atau sebaliknya, masih diperlukan studi empiris lebih lanjut

\section{Daftar Pustaka}

Akinbobola A. O. (2006). Effects of Cooperative and Competitive Learning Strategies on Academic Performance of Students in Physics, J. Res. in Educ., 3(1), 1-5.

Alexander, R. D. (1987). The Biology of Moral Systems. London: Aldine.

Brewer, M. B. (1979). Ingroup Bias in the Minimal Intergroup Situation: A 
cognitive-Motivational Analysis. Psychological Bulletin, 86, 307-324.

Buss, D. M. (1999). Evolutionary Psychology. London: Allyn \& Bacon.

Campbell, D. T. (1975). On the Conflicts Between Biological And Social Evolution And Between Psychology And Oral Tradition. American Psychologist, 30, 1103-1126.

Chen, G., Liu, C. H., \& Tjosvold, D. (2005). Conflict management for effective top management teams and innovation in China. Journal of Management Studies, 42, 277-300.

Chen, G., \& Tjosvold, D. (2002). Cooperative goals and constructive controversy for promoting innovation in student groups in China. Journal of Education for Business, 78, 46-50.

Coleman, P. T. (2011). Conflict, Interdependence, And Justice (The Intellectual Legacy of Morton Deutsch). Springer (E-Book).

Cohen E. G. (1994). Restructuring the classroom: Condition for productive small groups. Review of Educational Research, 64(1), 1- 35.

Crown, D. F., \& Rosse, J. G. (1995). Yours, Mine, and Ours: Facilitating Group Productivity Through the Integration of Individual and Group Goals. Organizational Behavior and Human Decision Processes, 64, 138-150.

De Cremer, D., \& Van Vugt, M. (1999). Social Identification Effects in Social Dilemmas: A transformation of motives. European Journal of Social Psychology, 29, 871-893.

Deci, E., Betley, G., Kahle, J., Abrams, L., \& Porac, J. (1981). When trying to win: Competition and intrinsic motivation. Personality and Social Psychology Bulletin, 7, 79-83.
Deutsch, M. (2008). A Career That Spans The History of Modern Social Psychology. In R. Levine, A. Rodrigues, \& L. Zelezny (Eds.), Journeys in Social Psychology: Looking back to inspire the future (221-240). New York: Psychology Press.

Deutsch, M. (1960). The Effects of Cooperation And Competition Upon Group Process. In D. Cartwright \& A. Zander (Eds.), Group dynamics (pp. 552-576). Oxford, England: Row, Peterson and Company.

Deutsch, M. (1973). The Resolution of Conflict. New Haven, CT: Yale University Press.

De Dreu, C. K. W. (2007). Cooperative outcome interdependence, task reflexivity, and team effectiveness: A motivated information processing perspective. Journal of Applied Psychology, $92,628-638$.

Epstein, J., \& Harackiewicz, J. (1992). Winning is not enough: The effects of competition and achievement orientation on intrinsic interest. Personality and Social Psychology Bulletin, 18, 128139.

Erev, I., Bornstein, G., \& Galili, R. (1993). Constructive intergroup com- petition as a solution to the free rider problem: A field experiment. Journal of Experimental Social Psychology, 29, 463478.

Fang Lu - Jia, Shi Kan \& Tjosvold Dean. (2010). Team Traning In China: Testing And Applying the Theory of Cooperation And Competition. Journal of Applied Social Psychology, 101-134.

Fiske, S. T. (2002). What We Now Know About Bias and Intergroup Conflict, The Problem Of The Century. Current Directions in Psychological Science, 11, 123-128. 
Harackiewicz, J., \& Sansone, C. (1991). Goals and intrinsic motivation: You can get there from here. In M. L. Maehr \& P. R. Pintrich (Eds.), Advances in motivation and achievement (Vol. 7, pp. 21-49). Green- wich, CT: JAI Press.

Jackson, S. E., Joshi, A., \& Erhardt, N. I. (2003). Recent research on team and organizational diversity: SWOT analysis and implications. Journal of Management, 29, 801-830.

Johnson, D. W., Maruyama, G., Johnson, R. T., Nelson, D., \& Skon, S. (1981). Effects of cooperative, competitive, and individualistic goal structures on achievement: A meta-analysis. Psychological Bulletin, 89, 47-62.

Johnson D. W., Johnson R. T., \& Holubec, E. J. (1986). Circle of Learning: Cooperation in the classroom. Edina MN: Interaction Book Company.

Johnson, D. W., \& Johnson, R. T. (1989). Cooperation and competition: Theory and research. Edina, MN: Interaction Book Co. Johnson, D. W., \& and Smith, K.A. 1998b,

Johnson, D. W., \& Johnson, R. T. (2005). New developments in social interdependence theory. Genetic, Social, and General Psychology Mono- graphs, 131, 285-358.

Kolawole, E. B. (2008). Effects of Competitive and Cooperative Learning Strategies On Academic Performance Of Nigerian Students In Mathematics. Educational research and review, 3(1), 033-037.

Kort, M. S. (1992). 'Down from the Podium'. In E.S. Samuel (Eds.), New

Leung, K. (1996, June). The role of harmony in conflict avoidance. Paper presented at the $50^{\text {th }}$ anniversary conference of the Korean Psychological Association, Seoul, South Korea.
Leung, K., Koch, P. T., \& Lu, L. (2002). A Dualistic Model of Harmony and Its Implications for Conflict Management in Asia. Asia Pacific Journal of Management, 19, 201-220.

Lewicki, R. J., McAllister, D. J., \& Bies, R. J. (1998). Trust and distrust: New relationships and realities. Academy of Management Review, 23, 438-458.

Mulvey, P., \& Ribbens, B. (1999). The effects of intergroup competition and assigned group goals on group efficacy and group effectiveness. Small Group Research, 30, 651-677.

Okebukola, P. (1985). The Relative Effectiveness of Cooperative vs Competitive Interaction Techniques in Strengthening Student Performance in Science classes. Science Education, 69, 501-509.

Okebukola, P. (1986). Impact of Extended Cooperative and Competitive Relationships on The Performance of Students in Science. Human Relations, $39,673-682$.

Osgood, C. E. (1973). "From Yang and Yin to and or but." Language 49.2: 380-412. Diunduh dari: http://www.jstor.org/ search. tanggal 16 November 2008.

Ostrom, T. M., \& Sedikides, C. (1992). The Outgroup Homogeneity Effect in Natural and minimal groups. Psychological Bulletin, 112, 536-552.

Pressel, B. E. (1992). A Perspective on the Evolution of Cooperative Thinking, in Davidson and Worksham (Eds). Enhancing Thinking Through Cooperative Learning NY, NY: College Teachers Press

Reeve, J., \& Deci, E. (1996). Elements of the competitive situation that affect intrinsic motivation. Personality and Social Psychology Bulletin, 22, 24-33. 
Sansone, C., \& Harackiewicz, J. M. (1996). "I don't feel like it": The function of interest in self-regulation. In L. L. Martin \& A. Tesser (Eds.), Striving and feeling: Interactions among goals, affect, and self- regulation (pp. 203-228). Mahwah, NJ: Erlbaum.

Sherif, M. (1966). In common predicament: Social psychology of intergroup conflict and cooperation. Boston: Houghton Mifflin.

Slavin, R. E. (1992). When and why does cooperative learning increase achievement? Theoretical and Empirical perspectives. In A.E. HertzLazarowitz and E.R. Miller (Eds), Interaction in Cooperative Groups 41-45). New York: Cambridge University Press.

Stahle, R. J. (1986). 'From Academic strangers to successful members of a cooperative learning Group. An inside the learning perspective'. In R.J. Stahle and B.R. Vansickle (Eds) Cooperative Learning in the Social Studies Classroom 26-30, Washington DC: National Council for Social Studies

Stanne, M. B., Johnson, D. W., \& Johnson, R. T. (1999). Does competition enhance or inhibit motor performance? A metaanalysis. Psychological Bulletin, 125, 133-154.

Tajfel, H., \& Turner, J. C. (1979). An integrative theory of intergroup conflict. In W.G. Austin \& S. Worchel (Eds.), The social psychology of intergroup relations (pp. 33-47). Monterey, CA: Brooks/ Cole.

Tauer, J., \& Harackiewicz, J. (1999). Winning isn't everything: Competition, achievement orientation, and intrinsic motivation. Journal of Experimental Social Psychology, 35, 209238.

Tauer, J., \& Harackiewicz, J. (2004). The
Effects of Cooperation And Competition On Intrinsic Motivation And Performance. Journal of Personality and Social Psychology, 86(6), 849-861.

Ting-Toomey, S., \& Oetzel, J. G. (2001). Managing intercultural conflict effectively. Thousand Oaks, CA: Sage.

Tjosvold, D. (1988). Effects of shared responssibility and goal interdependence on controversy and decision making between departments. Journal of Social Psychology, 128, 7-18.

Tjosvold, D. (1998). Cooperative and competitive goal approaches to conflict: Accomplishments and challenges. Applied Psychology: An Interna- tional Review, 47, 285-342.

Tjosvold, D., \& Sun, H. (2000). Social face in conflict among Chinese: Effects of affronts to person and position. Group Dynamics: Theory, Research, and Practice, 4, 259-271.

Tjosvold, D., Tang, M. L., \& West, M. A. (2004). Reflexivity for team innovation in China: The contribution of goal interdependence. Group and Organization Management, 29, 540-559.

Tjosvold, D., \& Yu, Z. Y. (2007). Group risk-taking: The constructive role of controversy in China. Group and Organization Management, 32, 653-674.

Tooby, J., \& Cosmides, L. (1988). The evolution of war and its cognitive foundations (Institute for Evolutionary Studies Technical Report 88-1). Diunduh dari:http://www.psych.ucsb.edu/resea rch/ cep/papers/Evolofwar.pdf. tanggal 6 Desember 2006.

Tse, D. K., Francis, J., \& Walls, J. (1994). Cultural differences in conducting intra- and inter-cultural negotiations: A Sino-Canadian comparison. Journal of International Business Studies, 24, 537-555. 
Van Lange, Paul. A. M., Kruglanski, Arie W., \& Higgins E. T. (2012). The Handbook of Theories of Social Psychology (Volume 2). Sage Publication Ltd.

Vugt, M. V., Gremer, D. D., \& Janssen, S. P. (2007). Gender Differences In Cooperation and Competition. Research Report, Association For Psychological Science, 18(1), 19-23. 